\title{
Acts Of Terrorism And Their Impacts On Stock Index Returns And Volatility: The Cases Of The Karachi And Tehran Stock Exchanges
}

Anh Phuong Nguyen, New Mexico State University

Carl E. Enomoto, New Mexico State University

\begin{abstract}
Terrorist attacks throughout the world have disrupted the flow of financial capital between nations and affected incomes, company profits and stock prices. This paper uses a GARCH $(1,1)$ model to determine how these attacks have affected two specific stock markets: one in Pakistan and the other in Iran. It was found that significant, but different, stock index return shifts and changes in volatility occurred in the two markets. These effects on stock returns have important implications for the economies involved and provide information about investor reaction to terrorism.
\end{abstract}

Keywords: terrorism, garch, al-Qaeda, Pakistan, Iran, stock index returns

\section{INTRODUCTION}

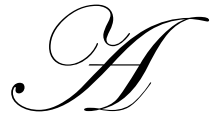

cts of terrorism affect lives directly, or indirectly, in virtually every part of the global economy. Terrorist strikes in Yemen, Kuwait, Indonesia, Jordan, Kenya, Pakistan, the Philippines, and the U.S. have been tied to the terrorist group known as al-Qaeda. According to Hoffman (2008), "AlQaeda is arguably one of the world's most formidable and resilient terrorist movements."

Acts of terrorism, such as the attack on the USS Cole in Yemen, the bombings in Madrid, Indonesia, and London, and the attacks on the World Trade Center and Pentagon in the United States, disrupt economic activity in the attacked nation and every nation that trades with the nation that was attacked. Profits of companies in many nations are adversely affected. Furthermore, due to the interconnectedness of global financial markets, it is no wonder that the effects of terrorism are felt in every corner of the world. In terms of their effects on stock markets, terrorist activities create turbulence and uncertainty among investors, forcing them to get out of the market quickly, precipitating a drop in equity prices and returns.

The purpose of this paper is to determine how several terrorist acts have affected stock markets in two nations: Pakistan and Iran. Pakistan has a population that is predominantly Sunni while Iran's population is predominantly Shia. In Pakistan, GDP per capita was estimated to be $\$ 2,600$ in 2008 while in Iran, GDP per capita was estimated to be $\$ 12,800$ in 2008 ("CIA world factbook," n.d.). Fatalities per capita from terrorist acts from 1986 to 2006 were 9.379 per one million people in Pakistan and 1.296 per one million people in Iran ("Terrorism statistics: Terrorist acts: Fatalities," n.d.). Pakistan is identified as a base for terrorist groups with 12 known terrorist organizations present in their nation while Iran has two (Terrorism statistics: Number of known terrorist organizations," n.d.). Since the 9/11/2001 terrorism attack in the U.S., the U.S. has enlisted Pakistan as a key ally in U.S.-led counterterrorism efforts. Meanwhile, Iran has been notorious for pursuing nuclear activities and in 2008 was described by the U.S. as "the world's leading state sponsor of terrorism" ("State Dept.: Iran leading state sponsor," 2009). With these substantial differences between the two nations, it is to be expected that stock returns will react differently in the two nations in response to a terrorist act committed in another nation. Furthermore, each 
nation has different trading partners and thus exports of each nation will be affected in a unique way depending on which outside nation was attacked. If, for example, an act of terrorism occurs in the U.S., as was the case with the World Trade Center attacks, Pakistan may be more affected than Iran due to closer ties between Pakistan and the U.S. In 2008, the U.S. imported $\$ 3.591$ billion worth of goods from Pakistan while importing only $\$ 104.1$ million worth of goods from Iran ("Foreign trade statistics: U.S. imports," n.d.). Due to the setback to the U.S. economy caused by the terrorist attacks of $9 / 11$, investors throughout the world would have reason to expect that U.S. incomes and imports from Pakistan and Iran would be adversely affected. Pakistan would likely be the nation more affected, given the greater amount of trade between the U.S. and Pakistan, and exporting firms in Pakistan would likely suffer more as a result. These expectations of decreased revenue and profit to firms in Pakistan would show up as a larger decrease in stock returns in Pakistan stock markets compared to the reaction in Iranian stock markets.

The different and unique effects on stock returns in the two nations due to acts of terrorism have important implications for investors, the economies involved, the distribution of world-wide income, further terrorist attacks, and an assessment of the true cost of terrorism in a global setting. In the example previously given where the World Trade Center attacks could lead to a much larger drop in stock returns in Pakistan compared to Iran, investors may redirect their financial investments away from companies in Pakistan. They may also redirect their financial investments away from Iranian companies, although to a smaller extent. With this loss in financial capital to Pakistan and Iran, companies in these two nations will find it increasingly more difficult and more costly to obtain funds to operate. The result could be a drop in national income with a change in the world distribution of income away from Pakistan and Iran.

Tikuisis (2009) has shown a relationship between weak states according to a failed state index and fatal terrorist attacks. If acts of terrorism lead to a loss of financial capital to a nation and contribute toward making the nation a failed state, it may well be the case that the nation is even more susceptible to future terrorist attacks. By identifying nations and stock markets most susceptible to the effects of terrorist acts, policies and actions may be designed to reduce problems associated with worldwide disruptions to the flow of financial capital.

The outline of the paper is as follows. In the next section, the data and methodology used for the study will be presented, followed by an empirical section and a brief description of several terrorist attacks in Madrid, Indonesia, London, Yemen, and the United States in 2001. The results will then be presented along with conclusions and a summary.

\section{METHOD}

Considered the oldest exchange in Pakistan, the Karachi Stock Exchange (KSE) was established in 1947 with only 5 listed companies. After more than 61 years, the KSE has now become "the biggest and most liquid exchange" in Pakistan with more than 663 listed companies. Business Week magazine announced that the KSE was "the best performing world stock market in 2002." Since 1991, foreign investors have been able to trade in the secondary market of the KSE which has further developed the exchange ("Karachi stock exchange (KSE)," n.d.).

Since the central leadership of al-Qaeda has been known to be in areas of Pakistan, stocks traded in the KSE may well be affected by acts of terrorism committed by al-Qaeda or on behalf of al-Qaeda. Investors may anticipate that future profits of companies within the nation will suffer due to either a drop in exports or due to a drop in domestic demand due to uncertainty about Pakistan's future given the possibility of repercussions against Pakistan from other nations. The likely result will be a drop in stock prices. The greater the impact of the terrorist strike and the anticipated repercussions, the larger will be the drop in stock prices. Correlations between acts of terrorism and stock market reactions have been empirically proven. After the $9 / 11$ terrorist attacks in the United States, the New York Stock Exchange and NASDAQ did not open until 9/17. In the first opening days, the DJIA decreased by 684 points, the largest one week point drop in the Dow's history ("Dow drops record 684 points," 2001). Ahmed and Farooq (2008) examined the effect of $9 / 11$ on the Karachi stock market and found a significant change in volatility during the post-9/11 period. Their study, however, deleted daily observations for the first four months after the 9/11 attack and they did not look at other acts of terrorism that could have affected the Karachi stock market. Other studies that have analyzed stock market reaction to terrorism include Karolyi and Martell (2005) who discovered an average negative effect of $-.83 \%$ in stock returns of 43 firms in various countries around 
the day of 75 terrorist attacks. Furthermore, Abadie and Gardeazabal (2003) investigated stock performance in the Basque country and found that when a reliable truce became apparent, stocks performed favorably and they performed unfavorably at the end of the cease fire.

Due to the interconnectedness of financial markets, it is reasonable to further assume that other stock exchanges have been affected. Such "spillover" effects have been noted by Floros (2008) between the Egyptian and Israeli stock exchanges and by Chan and Hooy (2003) between the U.S., Japan, Hong Kong, Singapore, South Korea, Taiwan, Indonesia, Malaysia, the Philippines, and Thailand. In this paper we examine the effects of several world-wide terrorist attacks, many of them associated with al-Qaeda, on the Karachi and Tehran stock exchanges. The Tehran stock exchange was established in 1967 and 420 companies are listed on the exchange ("About TSE: History," n.d.). The Tehran stock exchange in Iran was chosen in addition to the Karachi stock market because of its close proximity to Afghanistan, Pakistan, and Iraq, where al-Qaeda once had a presence. It was also chosen because of the suspected link between al-Qaeda and Iran as stated by Gunaratna (2003, pp. 194-195): "Iran received nearly 10 percent of Osama's outgoing calls from Afghanistan from mid-1996 to 1998, suggesting that Iran was maintaining a relationship with Al Qaeda even after he developed close ties with the Taliban in Afghanistan, a regime unfriendly toward Tehran." The relationship between Al-Qaeda and Iran, however, has been a tenuous one. According to CBS News (2003), some al-Qaeda leaders used "Iran as a sanctuary...safe from American attack." The article further stated that "The Iranians insist they would arrest anyone even suspecting of having al-Qaeda connections." Nevertheless, attacks by al-Qaeda can affect Iran indirectly through disruptions in its trade with those nations directly affected by al-Qaeda attacks. Because of these indirect effects and possible ties between al-Qaeda and Iran, stock prices and returns in the Tehran stock market could very well be affected by acts of terrorism committed on behalf of al-Qaeda. Thus stock index returns from the Tehran stock exchange were also selected to estimate the extended effects of terrorism.

Daily stock index figures for the Karachi stock exchange (KSE 100) from July 5, 1999 to September 19, 2008 were taken from www.finance.Yahoo.com and daily figures for the Tehran stock exchange (TEPIX) from January 2, 1999 to June 9, 2008 were taken from www.iranbourse.com. Daily stock index returns (market returns) were calculated as percent changes in the daily index figures which are equivalent to the following expression, $\log \left(\frac{I_{t}}{I_{t-1}}\right) * 100$, where $\mathrm{I}_{\mathrm{t}}$ is the stock index for day $\mathrm{t}$. These daily stock index returns (market returns) were used as dependent variables in estimating the effects of acts of terrorism on the Karachi and Tehran stock exchanges.

A simple model of the above effects of terrorism on market returns could be specified as below:

$r_{t}=\mu+v_{t}$

$\sigma_{t}^{2}=k$

In equation (1), $r_{t}$ is the daily market return (index return) in a given stock exchange, $\mu$ is a constant and $v_{t}$ is a random disturbance term. Thus daily market returns are modeled as fluctuating around the constant mean, $\mu$. The disturbance term, $v_{t}$, is the sum of all other factors in the current period affecting market returns. This would include news reports and information in period $t$ affecting future company profits, government policies announced in period t that would affect future company earnings, weather conditions, and acts of terrorism that may impact the economy's future. These factors could have negative or positive impacts on the returns. Hence, the distribution of $v_{t}$ would have a mean equal to 0 . In equation (2), $\sigma_{t}^{2}$, the variance of $v_{t}$, is assumed to be constant and equal to the value $\mathrm{k}$, for all time periods (the assumption of a homoskedastic disturbance term). 
However, the homoskedastic disturbance term assumption has been proven to be implausible. Researchers have noted that many financial time-series variables like stock index returns, exchange rates and inflation rates, exhibit changing variances over time with periods of low volatility (variance) followed by periods or clusters of high volatility. Thus the variance of the disturbance term in equation (2) must also be modified to account for heteroskedasticity (unequal variances). With the assumption of heteroskedasticity, the Nobel winner Engle (1982) proposed the Autoregressive Conditional Heteroskedasticity (ARCH) model and Bollerslev (1986) introduced the GARCH model as a generalization of Engel's work. The most widely used specification is the $\operatorname{GARCH}(1,1)$ model :

$$
\begin{aligned}
& r=\mu+\varepsilon_{t} \\
& \sigma_{t}^{2}=\varpi+\alpha \varepsilon_{t-1}^{2}+\beta \sigma_{t-1}^{2}
\end{aligned}
$$

The model in equations (3) and (4), the "mean equation" and "variance equation," is a GARCH $(1,1)$ model since the variance equation contains one lagged value of the squared disturbance term (the ARCH term) and one lagged value of the variance of the disturbance term (the GARCH term). The variance of $\mathcal{E}_{t}$, which is now denoted as $\sigma_{t}^{2}$, is no longer assumed to be constant but is allowed to change from period to period. It is explicitly modeled as a function of $\varepsilon_{t-1}^{2}, \sigma_{t-1}^{2}$ and the constant term, $\varpi$. The variable $\varepsilon_{t-1}^{2}$ and its coefficient, capture the effect of information or news on volatility in the previous period on this period's volatility. The variable $\sigma_{t-1}^{2}$ and its coefficient, capture the effect of the variance or volatility forecasted last period, on this period's volatility. Equation (4) thus implies that the variance at present is contingent upon last period's news and variance. If the sum of the coefficients of $\varepsilon_{t-1}^{2}$ and $\sigma_{t-1}^{2}$ is close to 1 , then volatility in market returns is said to be highly persistent which is a characteristic of stock index returns and other financial time-series variables.

To explicitly account for the systematic effects of acts of terrorism on daily market returns and volatility, the model has been adjusted as follows:

$$
\begin{aligned}
& r_{t}=\mu+\sum \rho_{i} D_{i}+\varepsilon_{t} \\
& \sigma_{t}^{2}=\varpi+\alpha \varepsilon_{t-1}^{2}+\beta \sigma_{t-1}^{2}+\sum \lambda_{i} D_{i} .
\end{aligned}
$$

In equation (5) $D_{i}$ is a dummy variable for a given act of terrorism and $\rho_{i}$ is the coefficient associated with the dummy variable. The value of the dummy variable is 1 for the period over which the terrorist act occurred and is 0 for all other days. If the act of terrorism changes investors' expectations of future company earnings in an unfavorable manner, then $\rho_{i}$ should be negative and daily market returns should fall. The new disturbance term, $\varepsilon_{t}$, is now the sum of all other random factors affecting market returns once the systematic effects of terrorism on market returns have been removed. In equation (6), since the effects and information about terrorism have been removed from $\varepsilon_{t}, \varepsilon_{t-1}$ and $\varepsilon_{t-1}^{2}$, the dummy variables representing effects of terrorist activities must be separately included to allow these activities to affect volatility of market returns as well as market returns themselves. There are several studies that use this technique (Fabozzi, Tunaru, and Wu, 2004; Long, 2008; Lin and Wang, 2005; Miles, 2002; Ahmed and Farooq, 2008; Chan and Hooy, 2003). ${ }^{1}$ 
The stock index returns (market returns) for the Karachi and Tehran stock exchanges are plotted in Figures 1 and 2. The changing amplitudes of returns in both exchanges show clusters of high volatility followed by clusters or periods of low volatility in returns which indicates that the GARCH model is appropriate for modeling market returns for these two cases. The dummy variables used in equations (5) and (6) are described as follows.

\section{Dummy variable D1: October 12, 2000, bombing of the USS Cole}

On October 12, 2000, a suicide bombing demolished the USS Cole, a guided missile destroyer in the Aden port of Yemen, resulting in the deaths of 17 sailors ("Attack on the USS Cole," n.d.). Al-Qaeda was attributed with organizing and implementing this attack. This event, which was one of the most significant acts of terrorism in the year 2000, happened in a port which has been an important trading center of southern Arabia since ancient times and has also been a major trading and refueling station since the Suez Canal opened in 1869. The dummy variable D1 is equal to 1 for the five days following the day of the event, October 12,2000, and is 0 for every other day in the sample.

\section{Dummy variable D2: September 11, 2001, World Trade Center attack (WTC)}

On September 11, 2001, there was a series of suicide attacks organized by al-Qaeda. Four jet airlines were hijacked; two of them deliberately crashed into the Twin Towers of the World Trade Center in New York City; the third one crashed into the Pentagon; and the forth jet crashed into a rural area in Pennsylvania ("September 11 attacks," n.d.). The attacks caused the deaths of nearly 3000 people, seriously destroyed the surrounding areas and resulted in post-event suffering consequences. On Oct 7, 2001, the U.S. moved into Afghanistan with the goal of destroying al-Qaeda, the Taliban regime and Osama bin Laden. The dummy variable D2 is equal to 1 for the five days following September 11, 2001, and is 0 for every other day in the sample.

\section{Dummy variable D3: Oct 12, 2002, the Indonesia bombing}

A blast exploded in a crowded district on Bali Island, Indonesia, killing 202 people and injuring many more. The Jemaah Islamiyah group that was believed to have some links to al-Qaeda, was blamed for organizing this attack ("Bali nightclub bombing," n.d.). The dummy variable D3 is equal to 1 for the five days following October 12, 2002, and is 0 for every other day in the sample.

\section{Dummy variable D4: March 20, 2003, Iraq war}

The Iraq war which began on March 20, 2003, involved the coalition of many countries including the US, the United Kingdom, Australia, Denmark and Italy. This war has had significant effects on Iraq and surrounding nations. The dummy variable D4 is 1 for the five days following March 20, 2003, and is 0 for every other day in the sample.

\section{Dummy variable D5: March 11, 2004, Madrid bombing}

A series of bombs exploded at the train system in Madrid on March 11, 2004. Nearly 200 people died and 1,755 people were wounded. A group inspired by the terrorist organization, al-Qaeda, was suspected of this attack in retaliation of the Spanish government's involvement in the Iraq War ("International relations: Terrorism," 2008). The dummy variable D5 is 1 for the five days following March 11, 2004, and is 0 for every other day in the sample.

\section{Dummy variable D6: July 07, 2005, bombing in London}

This variable is related to the bombing that occurred in the transport system in London on July 07, 2005, killing more than 30 people and injuring 700 ("London bombings toll rises to 37," 2005). An Islamist group inspired by al-Qaeda was suspected of carrying out this terrorist act. The purpose of this attack was the same as it was in Madrid one year ago: to threaten countries supporting the U.S. in the Iraq War. The UK was one of the most ardent supporters of the U.S. The dummy variable D6 is 1 for the five days following July 7, 2005, and is 0 for every other day in the sample. 


\section{Dummy variable D7: Feb 22 to Feb 27, 2006, Golden Mosque bombing}

This event included a series of attacks in five continuous days from Feb 22 to Feb 27, 2006. The first bombing started at the Golden Mosque in Samarra in Iraq, on Feb 22, 2006, severely damaging the mosque. A series of attacks in the following days in several cities of Iraq killed at least 165 people ("Officials in Iraq note approaching al-Askari mosque bombing anniversary," 2007). While this event was not linked to al-Qaeda, it had significant repercussions on neighboring countries. The dummy variable D7 is 1 for the five days following February 27, 2006, and is 0 for every other day in the sample. In the next section, the empirical results and the conclusions will be presented.

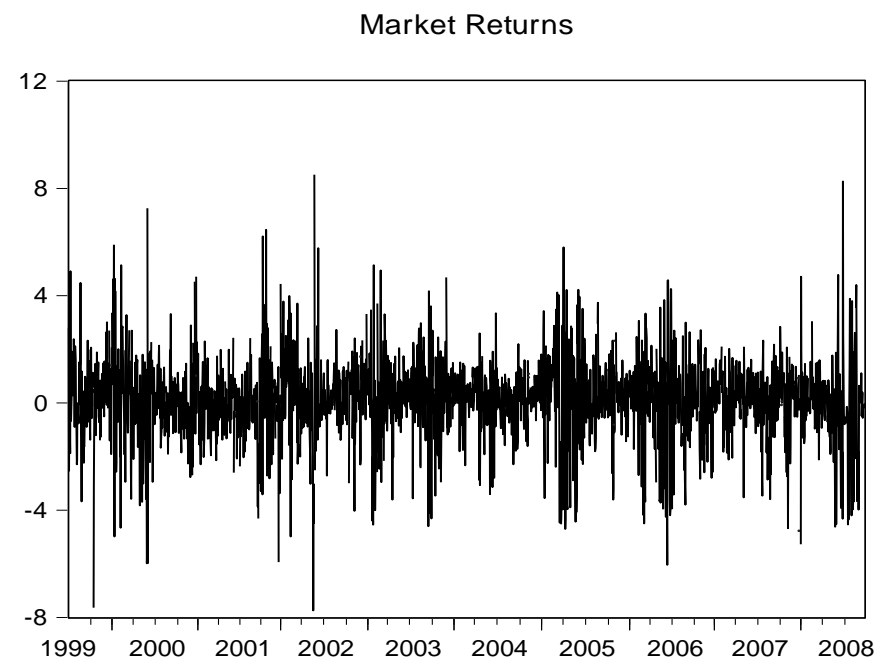

Figure 1: Market Index Returns for the Karachi Stock Exchange

Market Returns

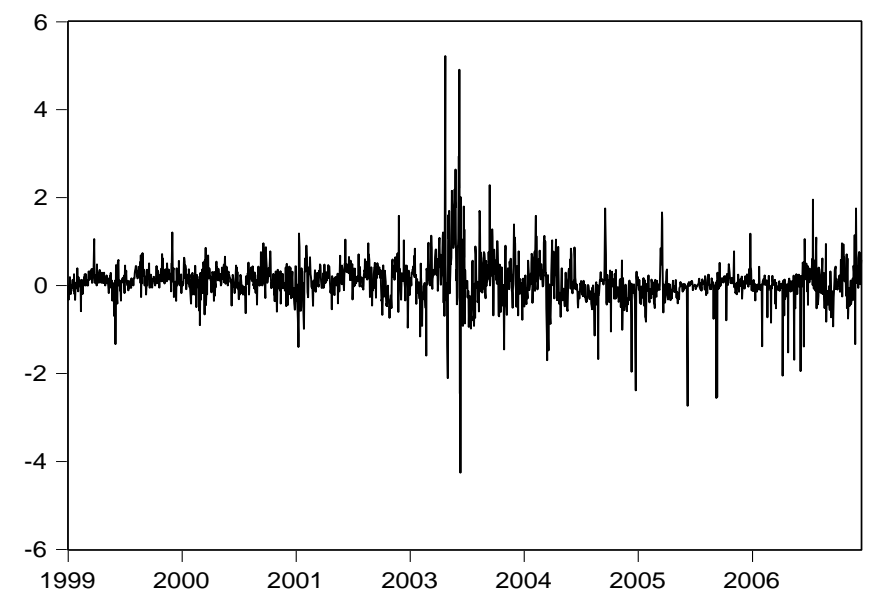

Figure 2: Market Index Returns for the Tehran Stock Exchange 


\section{RESULTS}

Table 1 contains the maximum likelihood estimates of the GARCH model for the Karachi and Tehran stock exchanges. ${ }^{2}$ The results show that the terrorist attacks on the USS Cole, the World Trade Center and London, along with the onset of the Iraq war, had significant effects on market returns in the Karachi stock exchange. The World Trade Center attack had the largest effect, pushing market returns down by $2.77 \%$. Terrorist acts that disrupt economic activity in the United States, push U.S. incomes and imports down and reduce exports of U.S. trading partners. Those nations that trade with U.S. trading partners will likewise be affected with decreases in their exports. These expectations of reduced exports from many nations to the U.S. and its trading partners would have caused investors worldwide to revise and lower their expectations of future company profits. The result is lower stock prices and returns for many companies and many nations, including Pakistan. Similar results occurred as a result of the attacks on the USS Cole and the London bombings in which al-Qaeda was a primary suspect.

The effect of the start of the Iraq war on market returns in the Karachi stock exchange was found to be positive. While this finding seems counterintuitive, Ahmed and Farooq (2008) found the same result and provide some rationale for this. They stated (p.73), "We claim that this sudden shift in the volatility dynamics of the KSE was not due to the reforms initiated by the SECP (Securities and Exchange Commission of Pakistan) but due to the unexpected beneficial effects of the terrorist attacks of $9 / 11 \ldots$ We argue that the unexpected benefits that Pakistan attracted, as an aftermath of terrorist attacks may be responsible for affecting the volatility dynamics of the KSE. Some of the benefits, such as a surge in remittances via formal channels, increase in export quotas for textiles to the EU and U.S., and debt rescheduling of country's debt, not only helped in improving the firm performances but also enhanced the liquidity and investor participation in the KSE." These indirect benefits to Pakistan discussed by Ahmed and Farooq could be responsible for the increased market returns found in our study for the period beginning with March 20, 2003.

\begin{tabular}{|c|c|c|c|c|c|c|}
\hline \multirow{2}{*}{\multicolumn{7}{|c|}{$\begin{array}{r}\text { Table 1: GARCH Model with Dummy Variables (f } \\
\text { Mean Equation }\end{array}$}} \\
\hline & & & & & & \\
\hline & \multicolumn{3}{|c|}{ Karachi Stock Exchange } & \multicolumn{3}{|c|}{ Tehran Stock Exchange } \\
\hline Variable & Coefficient & Z-statistic & P-value & Coefficient & Z-statistic & $\begin{array}{l}\text { P-value } \\
\text { - }\end{array}$ \\
\hline intercept- $\mu$ & $0.148142 *$ & 5.287725 & 0.0000 & $0.071998 *$ & 4.191684 & 0.0000 \\
\hline D1 & $-0.803426 *$ & -2.222278 & 0.0263 & 0.069213 & 0.611313 & 0.5410 \\
\hline D2 & $-2.767026 *$ & -3.999105 & 0.0001 & $-0.920484 *$ & -4.146305 & 0.0000 \\
\hline D3 & 0.392676 & 0.828026 & 0.4077 & -0.180831 & -0.698151 & 0.4851 \\
\hline D4 & $1.017065 *$ & 2.621292 & 0.0088 & 0.192025 & 1.139653 & 0.2544 \\
\hline D5 & 0.015704 & 0.055306 & 0.9559 & 0.459486 & 1.380318 & 0.1675 \\
\hline D6 & $-0.354673 *$ & -3.482663 & 0.0005 & $-0.477615 *$ & -7.359543 & 0.0000 \\
\hline D7 & -0.205894 & -0.125728 & 0.8999 & -0.117098 & -1.773567 & 0.0761 \\
\hline \multicolumn{7}{|c|}{ Variance Equation } \\
\hline intercept- $\omega$ & $0.519852 *$ & 11.55923 & 0.0000 & $0.142953 *$ & 10.13974 & 0.0000 \\
\hline$\varepsilon_{t-1}^{2}$ & $0.317838 *$ & 10.72455 & 0.0000 & $0.157390 *$ & 9.148360 & 0.0000 \\
\hline$\sigma_{t-1}^{2}$ & $0.487050 *$ & 15.12466 & 0.0000 & $0.418968 *$ & 7.236367 & 0.0000 \\
\hline D1 & -0.539953 & -1.941906 & 0.0521 & $-0.143749 *$ & -8.885383 & 0.0000 \\
\hline D2 & 0.473495 & 0.222903 & 0.8236 & -0.054157 & -0.485981 & 0.6270 \\
\hline D3 & $-0.603833 *$ & -2.105409 & 0.0353 & -0.070981 & -0.489522 & 0.6245 \\
\hline D4 & $-1.075723 *$ & -2.441732 & 0.0146 & -0.126360 & -1.208952 & 0.2267 \\
\hline D5 & $-0.536791 *$ & -3.916450 & 0.0001 & 0.072304 & 0.241662 & 0.8090 \\
\hline D6 & $-0.560669 *$ & -4.225646 & 0.0000 & $-0.148019 *$ & -15.06095 & 0.0000 \\
\hline D7 & 2.543766 & 0.972564 & 0.3308 & $-0.145055 *$ & -10.91513 & 0.0000 \\
\hline $\begin{array}{l}* \text { These coef } \\
\dagger \text { D1 }=\text { USS } \\
\text { D7 }=\text { Golde }\end{array}$ & $\begin{array}{l}\text { ts are signific } \\
\text { D2=World T } \\
\text { sque }\end{array}$ & $\begin{array}{l}\text { he } 5 \% \text { level } \\
\text { enter; D3= }\end{array}$ & 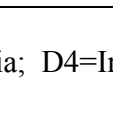 & $\mathrm{D} 5=\mathrm{Ma}$ & Condon; & \\
\hline
\end{tabular}


In the variance equation for the Karachi stock exchange, the sum of the coefficients of $\varepsilon_{t-1}^{2}$ and $\sigma_{t-1}^{2}$ was positive and less than one which is a requirement of the model. ${ }^{3}$ The attacks in Indonesia, Madrid and London, along with the onset of the Iraq war, all had significant, negative effects on volatility of market returns. These results are compatible with would happen following an act of terrorism. After the initial impact on market returns (given by the mean equation of the GARCH model), news and information are distributed to investors worldwide. If investors are uncertain about the future profits of companies due to a decrease in their exports or due to a drop in domestic demand because of a drop in consumer confidence and spending, then some investors may stay out of the stock market, leading to a reduction in trading activity and a reduction in volatility of market returns.

In the Tehran stock market, the attacks on the world trade center and the bombing in London that induced a decrease in returns in the Karachi stock exchange, also significantly reduced market returns. These results were again anticipated even though Iran was not directly implicated in either attack. The fact that the U.S. and London were attacked set back both economies affecting the trading partners of each. The uncertainty over future profits would affect investors leading to a decrease in returns in the Iranian stock exchange.

Furthermore, the world trade center attack reduced stock index returns in the Tehran Stock exchange (by $0.92 \%$ ) but to a smaller extent than it reduced stock index returns in the Karachi Stock exchange (2.76\%). Additionally, the start of the Iraq war that subsequently led to an increase in market returns in the Karachi stock exchange had no effect on the Tehran stock exchange. One reason for this lack of reaction in the Iranian stock market could be that the events that led up to the Iraq war, including the shipping of military vehicles and equipment by the U.S. in October 2002 to the Persian Gulf ("Attacking Iraq," n.d.), may have led investors to anticipate some sort of U.S.-led invasion into Iraq before the actual invasion occurred. Thus investors may have already affected stock prices and returns with their trading activity in anticipation of the start of the Iraq war, well before the start of the war. When the war actually started, stock prices had already accounted for it and no further reaction took place. Moreover, as was suggested in the introduction, Pakistan has been a vital ally in US-led counter terrorism efforts. Pakistan investors would consider those events related directly to the US more significant and having stronger effects on their future returns, than would Iranian investors.

In the variance equation for the Tehran stock exchange, the sum of the coefficients of $\varepsilon_{t-1}^{2}$ and $\sigma_{t-1}^{2}$ was also positive and less than one. The attack on the USS Cole, the bombing in London and of the Golden Mosque in Iraq, significantly reduced volatility in returns. Knickmeyer and Ibrahim (2006) stated the following, concerning the bombing of the Golden Mosque: "...the bombing was the most destructive attack on a major shrine since the U.S. invasion, and Iraqi leaders said it was meant to draw Shiites and Sunnis into war. "This is as 9/11 in the United States," said Adel Abdul Mahdi, a Shiite and one of Iraq's two vice presidents." Sunni mosques were later attacked in retribution for the attack against the Golden Mosque. Due to the uncertainty created by this situation on future company profits in Iran, it would again be anticipated that some investors would stay out of the stock market, leading to a reduction in trading activity and a reduction in volatility of market returns.

In comparison to the Karachi stock exchange, there were fewer significant events affecting the variance of returns and the coefficients in the variance equation were also smaller in the Tehran stock market. While all the coefficients of the significant dummy variables of the Karachi stock exchange were less than -0.5 , all of the coefficients of significant events in the Tehran stock exchange were approximately -0.14 . This again seems to substantiate the reason mentioned before, that due to a greater adherence to anti-terrorism activities, investors in the Pakistan stock market may be more sensitive to terrorist attacks than investors in neighboring Iran.

The GARCH model was also estimated for the Karachi and Tehran stock index returns when the dummy variables took on a value of 1 for 10 days following the act of terrorism and 0 for every other day. ${ }^{4}$ There are several reasons for considering a longer "event window" following acts of terrorism. ${ }^{5}$ 1) The assimilation of information in one stock market may be less efficient than in another stock market if investors do not receive (or react to) news reports and other information in a timely manner. 2) It may take longer for an act of terrorism to affect one nation compared to another. While some nations directly trade with an attacked nation and thus be immediately affected, other nations may only indirectly trade with the attacked nation through other nations. 3) The effects of terrorism may be longer lasting in one nation due to the structure of its economy and the types of 
companies and industries in that nation. The new estimates are presented in Table 2.

In the Karachi stock exchange, attacks against the USS Cole and the World Trade Center still had negative impacts on market returns. Furthermore, the disappearance of the decrease in return volatility following the London bombing and the start of the Iraq war, was consistent with the disappearance of the decrease in market returns for the two events. Investors had enough time and information to revise their expectations they formed five days following the attacks and returned to trading in equity markets. In the Tehran stock exchange, the attacks against the World Trade Center and the London bombings still had negative effects on market returns, 10 days after the attacks. The attack against the USS Cole, the bombing in Madrid and of the Golden Mosque, now had time to affect market returns. Volatility of returns was still reduced within 10 days of the attacks against the USS Cole and the Golden Mosque in Iraq.

\section{DISCUSSION \& CONCLUSION}

Acts of Terrorism have direct and indirect effects on almost every nation in the world. The nation in which the terrorist attack occurs is the most devastated and the effects range from loss of life to loss of future earnings and company profits. The drop in incomes and subsequent drop in imports and trade provide the transmission mechanism to other economies through which the effects of terrorism are felt. The interconnectedness of financial markets also links nations and transmits the effects of terrorism. In this paper a GARCH model has been estimated to determine the effects of acts of terrorism on market returns in the Karachi and Tehran stock exchanges. Pakistan and Iran were two nations that reportedly had ties or relationships with al-Qaeda at one time or another and would be affected directly or indirectly by terrorist attacks associated with al-Qaeda. Short-run and long-run effects of terrorism on stock returns and volatility of returns were also examined. It was found that (i) The attack on the World Trade Center and the bombing in London reduced market returns in both the Karachi and Tehran stock exchanges, 5 days after the attacks occurred. (ii) The attack against the USS Cole and the start of the Iraq war affected market returns in the Karachi stock exchange, 5 days after the attacks occurred. (iii) Whenever volatility of market returns was significantly affected by a terrorist attack, it was reduced as the uncertainty created by the attack led to a reduction in trading activity among some investors. (iv) The bombing in London and the bombing of the Golden Mosque, reduced market returns in the Tehran stock exchange within 10 days of the initial attacks. What this analysis shows is that investors have different expectations concerning the effects of terrorist attacks on company profits. An act of terrorism occurring in a nation may lead investors to expect that company profits in Pakistan will be adversely affected while company profits in Iran will be largely unaffected. There are many reasons for this. Pakistan's exports to the attacked nation or trading partners of the attacked nation may be greater than Iran's exports to those same nations. There may be a greater likelihood of sanctions being imposed on Pakistan than on Iran by the rest of the world due to the terrorist attack. Pakistan may have more financial assets at risk abroad than does Iran. The result of all this is that while terrorism affects many different stock exchanges, it affects them differently.

More particularly, for investors who take risks and invest in the Karachi and Tehran markets or in markets similar to these two, the results give insights as to how to minimize losses in post terrorism periods. Given the characteristics of each stock exchange, investors can make predictions about the reaction of the market after a terrorist attack and anticipate the magnitude of the effects. Those estimates can help investors evaluate investment decisions and select hedging strategies to neutralize the risk after such events.

Due to spillover effects of terrorism into different financial markets, the global cost of terrorism may be much higher than originally anticipated. The reduction in market returns and disruption to financial activity may distort the allocation of financial capital worldwide. Investors may seek out safe-low return investments in search of short-run profits rather than investing in companies that are perceived to be in nations whose financial markets are more affected by terrorist attacks. The loss of capital to those nations who are most affected by terrorism, may be the nations who need it the most. The result may be an undesirable distribution of world income with poor nations becoming poorer and an increasing disparity between the haves and have-nots. 


\begin{tabular}{|c|c|c|c|c|c|c|}
\hline \multirow{2}{*}{\multicolumn{7}{|c|}{$\begin{array}{r}\text { Table 2: GARCH Model with Dummy Variables (f } \\
\text { Mean Equation }\end{array}$}} \\
\hline & & & & & & \\
\hline \multicolumn{4}{|c|}{ Karachi Stock Exchange } & \multicolumn{3}{|c|}{ Tehran Stock Exchange } \\
\hline Variable & Coefficient & Z-statistic & P-value & Coefficient & Z-statistic & P-value \\
\hline intercept- $\mu$ & $0.138009 *$ & 5.123999 & 0.0000 & $0.062049 *$ & 7.479465 & 0.0000 \\
\hline D1 & $-0.539490 *$ & -1.980275 & 0.0477 & $0.141650 *$ & 3.226716 & 0.0013 \\
\hline D2 & $-2.106641 *$ & -2.982048 & 0.0029 & $-0.427596 *$ & -2.204205 & 0.0275 \\
\hline D3 & 0.610574 & 1.467700 & 0.1422 & 0.138402 & 1.500026 & 0.1336 \\
\hline D4 & 0.377360 & 1.076670 & 0.2816 & 0.233777 & 1.376016 & 0.1688 \\
\hline D5 & 0.326415 & 1.463523 & 0.1433 & $0.465745 *$ & 2.515628 & 0.0119 \\
\hline D6 & -0.358851 & -1.257742 & 0.2085 & $-0.382406 *$ & -3.057108 & 0.0022 \\
\hline D7 & -0.733560 & -0.984442 & 0.3249 & $-0.099373 *$ & -4.426384 & 0.0000 \\
\hline \multicolumn{7}{|c|}{$\begin{array}{l}\text { Variance Equation } \\
\end{array}$} \\
\hline intercept- $\omega$ & $0.179921 *$ & 9.732886 & 0.0000 & $0.060925 *$ & 25.55696 & 0.0000 \\
\hline$\varepsilon_{t-1}^{2}$ & $0.189610 *$ & 11.37164 & 0.0000 & $0.469206 *$ & 17.98502 & 0.0000 \\
\hline$\sigma_{t-1}^{2}$ & $0.737852 *$ & 41.85675 & 0.0000 & $0.262049 *$ & 11.35193 & 0.0000 \\
\hline D1 & -0.127805 & -0.947888 & 0.3432 & $-0.051433 *$ & -5.717756 & 0.0000 \\
\hline D2 & 1.058575 & 0.679618 & 0.4967 & 0.131811 & 0.814301 & 0.4155 \\
\hline D3 & -0.000129 & -0.000620 & 0.9995 & $-0.062419 *$ & -29.36433 & 0.0000 \\
\hline D4 & -0.244216 & -0.866033 & 0.3865 & -0.010179 & -0.153256 & 0.8782 \\
\hline D5 & $-0.168035 *$ & -2.478719 & 0.0132 & 0.078805 & 0.398164 & 0.6905 \\
\hline D6 & -0.094676 & -0.566121 & 0.5713 & -0.036684 & -1.269288 & 0.2043 \\
\hline D7 & 0.901849 & 0.625189 & 0.5318 & -0.059317 * & -19.63935 & 0.0000 \\
\hline $\begin{array}{l}* \text { These coeff } \\
\dagger \text { D1 }=\text { USS C } \\
\text { D7 }=\text { Golden }\end{array}$ & are significar & $5 \%$ level & & 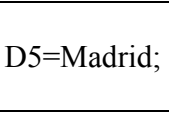 & ; & \\
\hline
\end{tabular}

As stated earlier, Tikuisis (2009) has shown a relationship between weak states according to a failed state index, and fatal terrorist attacks. If acts of terrorism disrupt financial markets in a nation and contribute towards making the nation a failed state, it may open up the nation to future terrorist attacks. To prevent these undesirable consequences from acts of terrorism, governments and nations may need to design policies to intercede in financial markets at the first sign of a terrorist attack, even if it is on foreign soil. Policies such as lowering interest rates and easing credit restrictions along with government stimulus spending, may be the temporary bridge the nation's economy needs to support investors' confidence until stability in stock markets is again achieved. Furthermore, for events having long lasting effects on returns such as the World Trade Center attack or long lasting effects on variance of returns such as the Madrid bombing, the government and companies of the nation can issue more powerful financial tools to reduce risk and keep investors actively participating in the market after acts of terrorism. Financial tools such as volatility options, bonds associated with terrorism events or insurance programs that protect investors after terrorist attacks can help reduce the likelihood of a market crash. The results from the GARCH model can help to assess the benefits of these tools in terms of what damages and disruptions to financial markets may be avoided with their use.

In summary, if the true cost of terrorism is much higher and more widely distributed worldwide than what was originally thought, then more resources need to be allocated to the fight against global terrorism. Furthermore, with almost every nation affected by terrorism, a more unified effort to fight terrorism seems to be justified.

\section{NOTES}

1. Event studies that are performed on daily stock returns of individual companies often only look at shifts in mean returns. In these cases, the $\mathrm{ARCH}$ and $\mathrm{GARCH}$ models are less often used. However, in event studies that analyze stock index returns where the event is political, economic, or a natural crisis, the ARCH and GARCH models have become more popular since they allow for changes in mean market returns and changes in volatility of returns. 
2. In estimating the GARCH model, the likelihood function that is maximized is:

$$
\begin{aligned}
& \ln L=-\frac{T}{2} \ln (2 \pi)-\frac{T}{2} \ln \sigma_{t}^{2}-\frac{1}{2} \sum_{t=1}^{T} \frac{\varepsilon_{t}^{2}}{\sigma_{t}^{2}} \text {, where T is the total } \\
& \text { number of observations and } \sigma_{t}^{2}=\varpi+\alpha \varepsilon_{t-1}^{2}+\beta \sigma_{t-1}^{2}+\sum \lambda_{i} D_{i} .
\end{aligned}
$$

3. For the unconditional variance to exist, this condition must be satisfied. See Davidson and MacKinnnon (2004, p. 589).

4. The GARCH model was also estimated when the dummy variables took a value of 1 for 7 days after the event and 0 for every other day. The results were similar to those reported in Table 2.

5. The event window was not extended beyond 10 days to avoid the possibility of other events overlapping the terrorist attack in question.

\section{AUTHOR INFORMATION}

Anh Nguyen received a Master of Arts degree in Economics at New Mexico State University in 2009. Growing up in Vietnam, she studied mathematics, physics and economics and she received a Bachelors Degree in Foreign Trade Economics at the Foreign Trade University in Hanoi. Her research interests include options pricing and applications of the Garch model.

Carl Enomoto is a Professor of Economics at New Mexico State University where he has been teaching for 26 years. He received his Ph.D. in Economics from Texas A\&M University in December, 1982. His research interests include macroeconomics, current social issues, mathematical models and econometrics.

\section{REFERENCES}

1. Abadie, A., \& Gardeazabal, J. (2003). The Economic costs of conflict: A case study of the Basque country. The American Economic Review, 93(1), 113-132.

2. About TSE: History (n.d.). Retrieved August 10, 2009, from http://www.iranbourse.com/Default.aspx?tabid=56.

3. Ahmed, S., \& Farooq, O. (2008). The effect of 9/11 on the stock market volatility dynamics: Empirical evidence from a front line state. International Research Journal of Finance and Economics, 16, 71-83.

4. Attack on the USS Cole (n.d.). Retrieved August 10, 2009, from http://www.al-bab.com/yemen/cole1.htm.

5. Attacking Iraq-countdown timeline (n.d.). Retrieved August 10, 2009, from http://www.globalsecurity.org/military/ops/iraq-timeline.htm.

6. Bajoria, J. (2008). Backgrounder: al-Qaeda. Council on Foreign Relations. Retrieved August 7, 2009, from http://www.cfr.org/publication/9126/.

7. Bali nightclub bombing (n.d.). Retrieved August 10, 2009, from http://www.globalsecurity.org/security/ops/bali.htm.

8. Bollerslev, T. (1986). Generalized autoregressive conditional heteroskedasticity. Journal of Econometrics, 31 (3), 307-327.

9. CBS News. (2003). Iran a safe haven for al-Qaeda? Retrieved August 7, 2009, from http://www.cbsnews.com/stories/2003/05/18/world/main554415.shtml?tag=contentMain; contentBody.

10. Chan, T., \& Hooy, C.W. (2003). On volatility spillovers and dominant effects in east Asia; Before and after 9/11. Retrieved August 7, 2009, from http://mpra.ub.uni-muenchen.de/2032/.

11. CIA world factbook (n.d.). Retrieved August 10, 2009, from https://www.cia.gov/library/publications/theworld-factbook/

12. Davidson, R., \& MacKinnon, J.G. (2004). Econometric theory and methods. New York, NY: Oxford University Press. 
13. Dow drops record 684 points as jittery markets reopen (2001). Retrieved August 10, 2009, from http://www.courant.com/topic/hc-attack-aldow-0918,0,5749796.story.

14. Enders, W., \& Sandler, T. (2006). The Political economy of terrorism, New York, NY: Cambridge University Press.

15. Engel, R.F. (1982). Autoregressive conditional heteroscedasticity with estimates of the variance of United Kingdom inflation. Econometica, 50(4), 987-1007.

16. Fabozzi, F.J., \& Tunaru, R. (2004). Modeling volatility for the Chinese equity markets. Annals of Economics and Finance, 5, 79-92.

17. Floros, C. (2008). Modelling volatility using garch models: Evidence from Egypt and Israel. Middle Eastern Finance and Economics, 2, 31-41.

18. Foreign Trade Statistics: U.S. imports (n.d.). U.S. census bureau. Retrieved August 10, 2009, from http://www.census.gov/foreign-trade/statistics/product/enduse/imports/c5070.html.

19. Gertz, B. (2004). CIA points to continuing Iran tie to al Qaeda. Retrieved August 10, 2009, from http://www.jihadwatch.org/archives/002611.php.

20. Greene, W.H. (2003). Econometric analysis, 5th ed. Upper Saddle River, New Jersey: Pearson Hall.

21. Gunaratna, R. (2003). Inside al Qaeda, New York, NY: Berkley Publishing Group.

22. Hoffman, B. (2008). Al-Qaeda. Retrieved August 10, 2009, from http://encarta.msn.com/text $701610346 \quad$ 0/Al-Qaeda.html.

23. International relations: Terrorism (2008). Retrieved August 10, 2009, from http://www.fco.gov.uk/en/about-the-fco/country-profiles/europe/spain/?profile=intRelations\&pg=4.

24. Karachi stock exchange (KSE) (n.d.). Retrieved August 10, 2009, from http://www.advfn.com/StockExchanges/about/KSE/KarachiStockExchange.html.

25. Karolyi, G.A., \& Martell, R. (2005). Terrorism and the stock market. Retrieved August 10, 2009, from http://www.cob.ohio-state.edu/fin/dice/papers/2005/2005-19.pdf.

26. Knickmeyer, E., \& Ibrahim, K.I. (2006). Bombing shatters mosque in Iraq. Retrieved August 10, 2009 , from http://www.washingtonpost.com/wp-dyn/content/article/2006/02/22/AR2006022200454.html.

27. Lin, C., \& Wang, Y. (2005). An analysis of political changes on Nikkei 225 stock returns and volatilities. Annals of Economics and Finance, 6, 169-183.

28. London bombings toll rises to 37 (2005). Retrieved August 10, 2009, from http://news.bbc.co.uk/2/hi/uk news/4661059.stm.

29. Long, V.T. (2008). Empirical analysis of stock return volatility with regime change using Garch model: The case of Vietnam stock market. Working paper 084, Retrieved August 10, 2009 from http://www.vdf.org.vn/workingpapers/vdfwp084.pdf.

30. Miles, W. (2002). Financial deregulation and volatility in emerging equity markets. Journal of Economic Development, 27 (2), 113-126.

31. Officials in Iraq note approaching al-Askari mosque bombing anniversary (2007). Retrieved August 10, 2009, from http://terrorism-online.blogspot.com/2007/02/officials-in-iraq-note-approaching-al.html.

32. September 11 Attacks (n.d.). Retrieved August 10, 2009, from http://encarta.msn.com/encyclopedia_701509060/september_11_attacks.html.

33. State Dept.: Iran leading state sponsor of terrorism (2009). Retrieved August 10, 2009, from http://www.diplomacy44.com/blog/2009/05/02/state-dept-iran-leading-state-sponsor-of-terrorism/.

34. Terrorism statistics: Number of known terrorist organizations (n.d.). Retrieved August 10, 2009 from http://www.nationmaster.com/graph/ter_num_of_kno_ter_org_pre-number-known-terrorist-organizationspresent.

35. Terrorism statistics: Terrorist acts: Fatalities (n.d.). Retrieved August 10, 2009 from http://www.nationmaster.com/graph/ter ter_act 196 fat percap-1968-2006-fatalities-per-capita.

36. Tikuisis, P. (2009). On the relationship between weak states and terrorism. Behavioral Sciences of Terrorism and Political Aggression, 1(1), 66-79. 